\title{
Exploration of Career Differences in Career Interests of Students with Special Needs
}

\author{
Ainun Heiriyah, Rudi Haryadi \\ Universitas Islam Kalimantan Muhammad Arsyad Al Banjari Banjarmasin \\ ainunheiriyah@gmail.com
}

Submitted: 2019-10-29, Revised: 2019-10-31, Accepted: 2019-11-26

\begin{abstract}
This study aims to analyze and identify trends in the career interests of students with special needs in the city of Banjarmasin and see if there are differences in career interest trends between students with special needs in primary and secondary schools. The research design used was a cross-sectional survey. The results show that there are differences in career interests of students with special needs related to the field of Social careers, Realistic career fields, Artistic career fields, Conventional career fields, Enterprising career fields, and Investigative career fields. Also, there was a small difference in career interest scores between elementary and middle school students, even though overall, the trend for interests was almost the same. Based on the research results obtained, it is recommended to further researchers to conduct further research on career interests for students with special needs with more specific characteristics and develop assessment instruments that are more relevant for students with special needs.
\end{abstract}

Keywords: Interest; Career; Special Needs Students

\section{Introduction}

Career is one of the fields that gets special attention in guidance and counseling. Ensuring that each student can actualize their talents and interests into the world of work is the main focus in this matter. Career guidance is a counselor assistance process for counselees. In experiencing growth, and career decision making throughout their lives, rationally, realistically based on information about the opportunities available in their environment so that they achieve success in their lives. One crucial area in adolescent life is the career field, especially about career readiness (Putranti, 2018). Logical consequence of adolescents where there are demands for career preparation.

Careers, in general, are related to the world of work. Super state's career is work, a position that leads to one's work life. (Brown \& Lent, 2004). Someone must be able to determine the career to be chosen, and planning career selection is a significant thing to achieve success (Sari, 2014). Careers can be said to have work experience that a person has in general, occupational categories such as teaching, accounting, medicine. In other words, a career is mostly sustainable and continues to develop since a person chooses his career to enter a non-productive period. So career selection is one of the essential things in one's developmental period, considering that this choice will have an impact on one's life in the future (Komara, 2016).

Furthermore, Super said that one's career development is a lifelong process and is determined from an early age (Brown \& Lent, 2004). This is why since childhood, a child has often been asked about matters of ideals. Some adults consider this to be less meaningful, but it is essential to realize that the child's model is an embryo of his career interests. (Kurniawan, Dahlan, \& Andriyanto, 2019). The ideals and hopes of a child's work in his time will develop into real career choices (Yulya Sari, 2017). In this case, children need guidance in developing their goals.

No exception for students with special needs, they also have aspirations and hopes for the future regarding what work is relevant to improving their welfare. Students with special needs are students who are significantly different from average students in terms of mental 
characteristics, sensory abilities, physical and neuromuscular, social and emotional behavior, communication skills, or a combination of two or more of the above (Komalasari \& Pamungkas, 2018). These students need more attention in terms of efforts to develop their careers. As the early history of the emergence of guidance and counseling in America, job guidance was initially given to people with disabilities to be able to function optimally in society (Kulkarni, 2016).

According to the National Socio-Economic Survey, the number of people with disabilities in Indonesia reaches around $2.45 \%$ of the total population of Indonesia. About $6.2 \%$ of them are school-age children (Kementrian Kesehatan RI,2014). This is a significant enough number to be worthy of reaping the attention of educators. South Kalimantan alone contributes around $14.4 \%$ of all people with disabilities in Indonesia (Kementrian Pendidikan dan Kebudayaan, 2017). There is no doubt that there are quite some inclusive and exceptional schools established in South Kalimantan, as a sample in Banjarmasin, there are around 39 schools that accommodate students with special needs. This fact is a challenge, especially for guidance and counseling practitioners who work in schools to help optimize student potential.

The problem that often arises in career guidance efforts for students with special needs is the problem of potential placement and distribution. In a study, found about $35 \%$ of students with special needs did not get the right investment in channeling their desires and potential (Lindstrom, Hirano, Ingram, DeGarmo, \& Post, 2019). In some cases, students with special needs have limitations in conveying their career desires so that it is difficult for teachers and parents to understand (Rule, Kahonde, \& Lorenzo, 2015). The incident caused a problem of misunderstanding between adults and students with special needs.

Also, the problem of stigma and ableism also colors the reason for the difficulty of students with special needs to fulfill their career interests. Some adults often say that the work desired by these students is not 'appropriate' for people who have limitations like them (Dean $\&$ Burke, 2017). The reason is because of the lack of a comprehensive understanding of the interests and talents of students with special needs (Zahrotul Badiah \& Muis, 2018). This assumption becomes something dangerous because it can kill the "seed" of the student's career.

Therefore, to facilitate career assistance for students with special needs, proper understanding is needed. An understanding of individuals can be affiliate with judgment. Career assessment generally involves assessments relating to individual characteristics, interests, and talents. Of these three things, attention is the most influential variable in career development. Benefits have three main components, namely personality, motivation or encouragement, and self-concept (Brown \& Lent, 2004). Understanding the career interests of students with special needs is an essential step in making careful career planning. (Mardini, 2015). Understanding the career interests of students with special needs is an essential step in making careful career planning (Devi \& Fachrurrozie, 2019). This shows that by making appropriate assessments of the career interests of students with special needs, it will be easier for guidance to mature their careers.

Based on this rationale, the researchers are interested in conducting research that explores trends in the career interests of students with special needs in the city of Banjarmasin. This exploration will be analyzed to get a comprehensive picture of trends in the career interests of students with special needs, specifically in the town of Banjarmasin.

\section{Methods}

This study uses a cross-sectional survey design using a comparison model between groups to uncover trends in career interests between groups of students with special needs at the elementary school level, and students with special needs at the secondary school level. 
The researchers distributed career interest questionnaires with 36 items arranged based on Holland's theory to 178 students with special needs in primary and secondary schools. The sample was determined using proportional-stratified random sampling from 5 districts in the city of Banjarmasin. Table 1 shows the sampling mapping

Table 1. Distribution of Research Samples

\begin{tabular}{llc}
\hline Level / Strata & \multicolumn{1}{c}{ School } & Sample \\
\hline Primary school & SDLB YPLB Banjarmasin & 89 \\
& SDLB B/C Dharma Wanita Banjarmasin & \\
& SLB Plus Madana Dunya & \\
& SLB Negeri Pelambuan (SD) & \\
Secondary school & SLB BC Paramita Graha & 45 \\
& SMPLB BC Dharma Wanita & \\
& SMPLB YPLB Pelambuan Banjarmasin & \\
& SMPLB Harapan Bunda & 44 \\
& SLB Negeri Pelambuan (SMP) & \\
& SMALBS B/C Dharma Wanita Persatuan & \\
& SMALB YPLB Pelambuan Banjarmasin & $\mathbf{1 7 8}$ \\
\hline & SLB Negeri Pelambuan (SMA) & Total \\
\hline
\end{tabular}

\section{Results and Discussion}

The survey results show that students with special needs in the city of Banjarmasin have different interests in career types. Furthermore, this study found apparent similarities between the career interests of students with special needs at the elementary school level and secondary school level. seen in table 2 below.

Table 2. Career Trends Interest Data for Students with Special Needs in Banjarmasin City

\begin{tabular}{lccc}
\hline Type of Career Interests $(\mathbf{n}=\mathbf{1 7 8})$ & $\mathbf{M}^{*}$ & $\mathbf{N}$ & Percentage \\
\hline Realistic $(\mathbf{R})$ & 3,82 & 87 & $27,4 \%$ \\
Investigatif $(\mathbf{I})$ & 2,48 & 15 & $4,7 \%$ \\
Artistic (A) & 3,20 & 46 & $14,5 \%$ \\
Social (S) & 3,82 & 90 & $28,4 \%$ \\
Enterprising (E) & 2,73 & 38 & $12 \%$ \\
Conventional $(\mathbf{C})$ & 2,96 & 41 & $13 \%$ \\
Total & $\mathbf{1 9 , 0 1}$ & $\mathbf{3 1 7}$ & $\mathbf{1 0 0 \%}$ \\
\hline
\end{tabular}

*Mean $=$ High: $\mathrm{pp}>3,81 ;$ Medium: $\mathrm{pp}=2,67-3,81 ;$ Low: $\mathrm{pp}<2,67$

Table 2 shows that students with special needs in the city of Banjarmasin tend to have more interest in the type of career that is social $(\mathrm{S}=90 ; 28.4 \%)$. This shows that most students with special needs in the city of Banjarmasin tend to prefer work that leads to activities that involve other people with an emphasis on helping, teaching, or providing assistance. Conversely, career types that are less interested in the investigative ( $I=15 ; 4.7 \%)$. This shows that the kinds of work that lead to activities that require observation, symbolic, systematic, and creative investigation of physical, biological, and cultural phenomena to understand and control these phenomena are less attractive to students with special needs in the city of Banjarmasin.

Furthermore, this study revealed an average measure of interest scores of students with special needs in the city of Banjarmasin for each type of interest. It found the average score of Realistic and Social interests of students with special needs in the town of Banjarmasin has the same number and classification in the high category $(\mathrm{R}=3,82, \mathrm{~S}=$ 3,$82 ; \mathrm{pp}>3,81$ ), while the average score of interest of students with special needs in the field 
of Artistic, Enterprising, and Conventional is in the medium category $(\mathrm{A}=3,20, \mathrm{E}=2,73, \mathrm{C}$ $=2,96 ; \mathrm{pp}=2,67-3,81)$, the average interest score in the Investigative field is in the low category $(I=2,48 ; \mathrm{pp}<2,67)$. This finding reinforces the results of the percentage of career interests of student voters with special needs stated earlier.

The study found apparent similarities between students' career interests and special needs at the elementary and secondary school levels. In more detail, these findings can be seen in table 3 .

Table 3. Comparison of Career Interest Trends of Students with Special Needs at Primary and Secondary Schools

\begin{tabular}{lcccccc}
\hline \multicolumn{1}{c}{ Type of Career Interests } & \multicolumn{3}{c}{ Primary school $(\mathbf{n}=\mathbf{8 9})$} & \multicolumn{3}{c}{ Secondary Schools(n = } \\
& \multicolumn{4}{c}{$\mathbf{8 9})$} \\
\cline { 2 - 7 } & $\mathbf{M}^{*}$ & $\mathbf{N}$ & Persentase & $\mathbf{M}^{*}$ & $\mathbf{N}$ & Persentase \\
Realistic (R) & 3,77 & 44 & $26,7 \%$ & 3,86 & 43 & $28,2 \%$ \\
Investigatif (I) & 2,48 & 9 & $5,5 \%$ & 2,48 & 6 & $3,9 \%$ \\
Artistic (A) & 3,19 & 23 & $13,9 \%$ & 3,21 & 23 & $15,1 \%$ \\
Social (S) & 3,82 & 46 & $27,9 \%$ & 3,82 & 44 & $28,9 \%$ \\
Enterprising (E) & 2,78 & 22 & $13,3 \%$ & 2,67 & 16 & $10,5 \%$ \\
Conventional (C) & 3,00 & 21 & $12,7 \%$ & 2,92 & 20 & $13,1 \%$ \\
Total Score & $\mathbf{1 9 , 0 5}$ & $\mathbf{1 6 5}$ & $\mathbf{1 0 0 \%}$ & $\mathbf{1 8 , 9 7}$ & $\mathbf{1 5 2}$ & $\mathbf{1 0 0 \%}$ \\
\hline
\end{tabular}

*Mean SD= High: pp > 3,78; Medium: $\mathrm{pp}=2,70-3,78$; Low: $\mathrm{pp}<2,70$

$*$ Mean SM= High: $p p>3,83$; Medium: $\mathrm{pp}=2,62-3,83$; Low: $\mathrm{pp}<2,62$

In table 3 at the elementary school level as well as at the secondary school level, students with special needs show a greater interest in social career types (SD $=46,51.7 \%$; $\mathrm{SM}=44 ; 49.4 \%$ ). On the other hand, students with special needs at both levels of primary and secondary school show little interest in Investigative career types ( $\mathrm{SD}=9,10.1 \%$; $\mathrm{SM}=$ $6 ; 6.7 \%)$.

This study also found the average score of interest of students with special needs in the city of Banjarmasin on each type of interest. At the elementary school level, the average social interest score of students with special needs in Banjarmasin is found to be high ( $\mathrm{S}=$ 3,$82 ; \mathrm{pp}>3,78$ ), while the average score of interest of students with special needs in the Realistic, Artistic, Enterprising and Conventional fields is in the medium category $(\mathrm{R}=3,77$, $\mathrm{A}=3,19, \mathrm{E}=2,78, \mathrm{C}=3,00 ; \mathrm{pp}=2,70-3,78)$, and the average score of interest in the Investigative field is in the low category $(\mathrm{I}=2,48 ; \mathrm{pp}<2,70)$.

Slightly different from that, at the secondary school level, the average score of Realistic student interests with special needs in the city of Banjarmasin is in the high category $(\mathrm{R}=3,86 ; \mathrm{pp}>3,83$ ), while the average score of interest of students with special needs in the fields of Social, Artistic, Enterprising, and Conventional is in the medium category ( $\mathrm{S}=3,82$, $\mathrm{A}=3,21, \mathrm{E}=2,67, \mathrm{C}=2,92 ; \mathrm{pp}=2,62-3,83)$, and the average score of interest in the Investigative field is in the low category $(\mathrm{I}=2,48$; $\mathrm{pp}<2,62)$.

Based on the findings of this study, most students with special needs in the city of Banjarmasin have a greater interest in working in the social field. This field includes work such as teachers, nurses, midwives, social workers, community managers / social organizations, advisors, or advocates. The situation is influenced by the social environment where students with special needs. Every day students with special needs interact with teachers, mentors, or tutors who teach various life skills, as well as lessons in school (Yunus, 2013). As stated that individuals, their behavior, and the environment will influence each other (Maftuhatin, 2014). Then the possibility of students choosing a career can be influenced by their observations on the surrounding environment. Each interaction with the environment will form experiences that strengthen self-efficacy in choosing a career (Piperopoulos \& Dimov, 2015). On the contrary, from this study, it was found that the types of careers that are 
less desirable by students with special needs in the city of Banjarmasin are the types of investigative careers. Investigative type relates to work orientation that leads to activities that require observational, symbolic, systematic, and creative investigation of physical, biological, and cultural phenomena to understand and control these phenomena, for example, lecturers, researchers, detectives, scientists, doctors, or psychologist (Sa'idah, 2018). It seems that this is due to the main characteristics of students with special needs who have various limitations making it difficult to achieve the appropriate criteria for working in that career path.

Some students with special needs, such as AD / HD children, tuna, and autistic children, have difficulty controlling emotions and tendencies in responding to a phenomenon. (Ameis et al., 2016). Whereas children with physical disabilities such as the blind, hearing impaired, speech impaired, and physically impaired have difficulty in carrying out the required tasks related to their limitations (Widiastuti, 2019). These characteristics are widely seen in students with special needs in the city of Banjarmasin and are aware of them, so the tendency to choose jobs that require logical inquiry skills tends to be less.

The next exciting finding in this study is about the average score of interest in each type of career. Although in some analyzes, the average score tends to be directly proportional to the number of applicants, but at the secondary school level, the average interest score of students with special needs tends to be higher in Realistic career types. It shows that although there are more enthusiasts for social career types, realistic career voters tend to have a higher level of interest than social career type voters.

The finding is an opportunity that counselors need to look at to develop the career interests of students with special needs. With a higher level of interest, it can be an asset for the student to be more active in pursuing his career and achieving career success (Gottfried, Bozick, Rose, \& Moore, 2016). Thus, the counselor who works in an environment of students with special needs must help clients examine the importance of the learning process and the particular learning experiences they already have that have helped shape their current career path (Aulia, 2019).

\section{Conclusions and Suggestions}

Based on the results of the study, it shows that career interests that are a trend for students with special needs in the city of Banjarmasin are types of social interests, which are related to work that lead to activities that involve the emphasis of others in helping, teaching. , or help. Meanwhile, career interests that are not popular for students with special needs are Investigative career interests. Both students with special needs at primary and secondary school levels tend to be interested in the types of social careers, and not too interested in the types of investigative careers.

Consideration in this study, it is recommended that future researchers develop a career interest instrument/questionnaire that is more relevant to the characteristics of students with special needs and conduct further research on the career interests of students with special needs with more specific aspects. Furthermore, guidance and counseling practitioners who work with students with special needs, must pay more attention and understand the career interests of students from an early age, so that it can be a modality for efforts to develop potential and help to actualize students' special needs.

\section{References}

Ameis, S. H., Lerch, J. P., Taylor, M. J., Lee, W., Viviano, J. D., Pipitone, J., ... Lai, M.-C. (2016). A diffusion tensor imaging study in children with ADHD, autism spectrum disorder, OCD, and matched controls: distinct and non-distinct white matter disruption and dimensional brain-behavior relationships. American Journal of Psychiatry, 173(12), $1213-1222$. 
Aulia, F. (2019). Konsep Konsep Pengembangan Layanan Bagi Anak Berkebutuhan Khusus pada Kurikulum 2013. JCOSE Jurnal Bimbingan Dan Konseling, 1(2), 31-35.

Brown, S. D., \& Lent, R. W. (2004). Career development and counseling: Putting theory and research to work. John Wiley \& Sons.

Dean, E., \& Burke, K. (2017). Career Development for Adults With Intellectual Disability: Pilot Outcomes From a Community-Based Employment Program. American Journal of Occupational Therapy, 71(4_Supplement_1), 7111520271p1-7111520271p1.

Devi, B. D. K., \& Fachrurrozie, F. (2019). Pengaruh Internal Locus Of Control, Lingkungan Keluarga, dan Prestasi Akademik Terhadap Kesiapan Bekerja di Luar Profesi Guru Melalui Kematangan Karier. Economic Education Analysis Journal, 8(1), 110-129.

Gottfried, M. A., Bozick, R., Rose, E., \& Moore, R. (2016). Does career and technical education strengthen the STEM pipeline? Comparing students with and without disabilities. Journal of Disability Policy Studies, 26(4), 232-244.

Komalasari, M. D., \& Pamungkas, B. (2018). Peningkatan Nilai Empati Siswa Berkebutuhan Khusus Melalui Pelatihan Mitigasi Bencana Berbasis Multisensoris di $\mathrm{Sd} \mathrm{N}$ Karanganyar dan Sd N Minggiran Yogyakarta. G-Couns: Jurnal Bimbingan Dan Konseling, 3(1).

Komara, I. B. (2016). Hubungan antara kepercayaan diri dengan prestasi belajar dan perencanaan karir siswa. Jurnal Psikopedagogia, 5(1), 33-42.

Kulkarni, M. (2016). Organizational career development initiatives for employees with a disability. The International Journal of Human Resource Management, 27(14), 16621679.

Kurniawan, B. C., Dahlan, S., \& Andriyanto, R. E. (2019). Hubungan Pola Asuh Orangtua dengan Pemilihan Karir Siswa. ALIBKIN (Jurnal Bimbingan Konseling), 7(1).

Lindstrom, L., Hirano, K. A., Ingram, A., DeGarmo, D. S., \& Post, C. (2019). "Learning to Be Myself": Paths 2 the Future Career Development Curriculum for Young Women With Disabilities. Journal of Career Development, 46(4), 469-483.

Maftuhatin, L. (2014). Evaluasi Pembelajaran Anak Berkebutuhan Khusus (ABK) di Kelas Inklusif di SD Plus Darul'ulum Jombang. Religi: Jurnal Studi Islam, 5(2), 201-227.

Mardini, S. (2015). Meningkatkan Minat Belajar Anak Berkebutuhan Khusus Di Kelas Reguler Melalui Model Pull Out Di SD N Giwangan Yogyakarta. Jurnal Pendidikan Sekolah Dasar Ahmad Dahlan, 2(1), 25-36.

Piperopoulos, P., \& Dimov, D. (2015). Burst bubbles or build steam? Entrepreneurship education, entrepreneurial self-efficacy, and entrepreneurial intentions. Journal of Small Business Management, 53(4), 970-985.

Putranti, D. (2018). Layanan Bimbingan Karir di Sekolah Menengah Kejuruan Berbasis Teaching Factory. Jurnal Konseling Komprehensif: Kajian Teori Dan Praktik Bimbingan Dan Konseling, 5(2), 42-47.

Rule, S., Kahonde, C., \& Lorenzo, T. (2015). "When I Grow up I Would Like to Be...": Factors Affecting Career Choice of Community Disability Workers in Southern Africa. International Journal of Disability, Development and Education, 62(5), 486-500.

Sa'idah, I. (2018). Memprediksi Minat Karier dan Pilihan Aspirasi Terhadap Pertimbangan Pilihan Karier Berdasarkan Social Cognitive Career Theory (SCCT). JKI (Jurnal Konseling Indonesia), 3(2), 48-56. 
Sari, M. (2014). Faktor-faktor yang mempengaruhi pemilihan karir menjadi akuntan publik oleh mahasiswa Departemen Akuntansi Fakultas Ekonomi UMSU Medan. JRAB: Jurnal Riset Akuntansi \& Bisnis, 13(2).

Widiastuti, N. L. G. K. (2019). Model Layanan Pendidikan Bagi Anak Berkebutuhan Khusus Yang Mengalami Kecacatan Fisik. Jurnal Ilmiah Ilmu Sosial, 5(1), 46-54.

Yulya Sari, N. (2017). Pengembangan Buku Panduan Orang Tua Untuk Mendukung Perencanaan Karir Siswa di Madrasah Aliyah Negeri Sidoarjo. Jurnal BK UNESA, 8(1).

Yunus, M. (2013). Meningkatkan Kemampuan Komunikasi Melalui Media Kartu Gambar Berseri Bagi Anak Autis. Jurnal Penelitian Pendidikan Khusus, 2(2).

Zahrotul Badiah, R., \& Muis, T. (2018). Pengembangan Aplikasi Cita-Cita Model Holland Untuk Siswa Berkebutuhan Khusus di Smp Negeri 13 Surabaya. Jurnal BK UNESA, $8(2)$. 
